\title{
"Race", Belonging and Emancipation: Trajectories and Views of the Daughters of Western Africa in Spain
}

\author{
Laia Narciso
}

check for updates

Citation: Narciso, Laia. 2021. "Race", Belonging and Emancipation: Trajectories and Views of the Daughters of Western Africa in Spain. Social Sciences 10: 143. https:// doi.org/10.3390/socsci10040143

Academic Editors: Zenia Hellgren and Bálint Ábel Bereményi

Received: 8 March 2021

Accepted: 7 April 2021

Published: 16 April 2021

Publisher's Note: MDPI stays neutral with regard to jurisdictional claims in published maps and institutional affiliations.

Copyright: (C) 2021 by the author. Licensee MDPI, Basel, Switzerland. This article is an open access article distributed under the terms and conditions of the Creative Commons Attribution (CC BY) license (https:/ / creativecommons.org/licenses/by/ $4.0 /)$.
Social and Cultural Anthropology Department, Autonomous University of Barcelona, 08193 Bellaterra, Spain; Laia.Narciso@uab.cat

\begin{abstract}
Young Spanish Black people born to migrant parents continue to be either invisible or problematized in public discourses, which project a monocultural and phenotypically homogeneous Europe. Research in countries with a long immigration history has shown that in the process of othering minorities, gender ideologies emerge as ethnic boundaries and feed the paternalistic treatment of women while accusing their families and communities of harming them through atavistic traditions. However, little research has focused on girls' and young women from West African immigration and Muslim tradition in Spain, a country where they represent the first "second generation". In order to gain a deeper insight into their processes and views, this paper describes and analyses the educational trajectories and transitions to adult life of a group of young women with these backgrounds who participated in a multilevel and narrative ethnography developed in the framework of a longitudinal and comparative project on the risk of Early Leaving of Education and Training in Europe (ELET). In the light of the conceptual contributions of the politics of belonging and intersectionality, the responsibilities regarding the conditions for gaining independence are relocated while assessing the role of the school in the processes of social mobility and the development of egalitarian aspirations in the labor market and in the family environment. The findings show how the limits encountered by these young women in their trajectories to an independent adult life are mainly produced by processes of racialization conditioned by class and gender, ironically in key spaces of social inclusion such as schools and the labor market rather than, or mainly by, an ethnic community that subjugates them.
\end{abstract}

Keywords: politics of belonging; narratives; black youth; gender ideologies; Spain

\section{Introduction}

While Europe was becoming a destination for many people undertaking an international migration project, the integration of immigrants and their descendants was emerging as a major political issue. This is reflected in the fact that integration policies and specific references to this population as vulnerable or at risk, occupy a central role in the European Commission's Europe 2020 strategy (European Commission 2010). However, this interest in managing diversity, especially ethnic and religious diversity, is explained by the discourse of the clash of civilizations and the politics of fear (Huntington 2000; Roth 2016), in view of the consideration that the multicultural project has failed or is incompatible with the European liberal tradition. This process has consolidated an imaginary of allegedly common values in which minorities, including their children born in Europe, and especially Muslims, have a problematic place. Not only has global Islamophobia increased (Morgan and Poynting 2016), but the formation of a joint grammar on citizenship, built on different models of integration and colonial pasts, has demonized certain citizens who have been considered a threat to the "common achievements" of European democracy (Kymlicka 2010; Modood et al. 2006). This includes the clearly racist and xenophobic positions of populist and far right movements, and progressive ones, which fear seeing some of their pillars threatened, such as gender equality and sexual freedom (Yilmaz 2012). Thus, gender ideology takes on a key role as a cultural marker turned into 
an ethnic border (Barth [1969] 1998; Alba 2005) and emerges in the hegemonic narratives of belonging that distinguish the "us" from the "others" in Europe and alter minorities (Yilmaz 2015).

Like the other southern European countries, Spain later joined the debates on citizenship and social cohesion, which began with the processes of family reunification led by Africans in the 1990s. The "migratory boom" in Spain and its role as a southern border, together with the onset of the world economic crisis and austerity policies have placed social inequality in Spain at the highest levels in the EU-27 with the greatest impact on migrant population (Parella 2016). The first generation of children of this migration flow has reached adulthood and it is necessary to assess the conditions they have encountered in their trajectories while coming of age. It is essential to consider that they have grown to a context characterized by the dualization of the labor market, youth unemployment and structural precariousness (Feixa et al. 2017) together with the weakening of social policies, previously underdeveloped and family-dependent, with weak policies to combat social inequality (Serracant 2013). Moreover, the children of immigrants from West Africa, a new ${ }^{1}$ young generation of Black Spaniards, are generally invisible or represented in a problematic way through a discourse of paternalistic subalternity, especially women, including those born in Spain. They emerge into the public sphere when the limits between cultural diversity and fundamental rights are addressed, in issues such as female genital mutilation or arranged and/or polygyny marriage, from perspectives that criminalize their community (Narciso and Carrasco 2017).

However, Spanish research, prolific in works on the high academic disadvantage ${ }^{2}$ of the children of immigrant families since they first arrived in schools at the turn of the century, with few exceptions, has not analyzed the social processes that affect young people from these origins (Narciso 2010). Although according to data from the Institute for National Statistics (INE) they represent 6\% of the foreigners in this region, there is a population hidden in the data due to the processes of nationalization, and they have maintained their presence over three decades, going from initial male migration patterns to family ones, with a first "second generation" who have spent their entire school career in Catalonia and who face specific experiences of racial discrimination in school, the labor market and public space (Vives and Sité 2010).

This article aims to contribute to filling this gap and explores the academic and emancipation trajectories of young people born in Spain to immigrants of Gambian and Senegalese origin, specifically focusing on young women, and gauge their impact on the ties of belonging and the processes of collective identification, reflecting on the effect of their experiences of racism and sexism. Firstly, the educational paths followed are described. Secondly, it analyses how the social positions they occupy in relation to the hegemonic discourses and politics of belonging have affected their daily lives, detailing the processes of racialization experienced in the school. Finally, their processes of identity negotiation with the previous generation and their gender values and ideologies are examined. Both contrast with the social representations that project a retrograde community and young women subjected to tradition. Instead, the agency of these young women emerges to confront both the patriarchal forms of power produced in the community in the transnational context and the racialization experienced in the spaces of contact with the majority population.

\section{Intersectionality, Citizenship and Belonging}

The relevance of migration and youth studies derives from their privileged position in the political agenda on integration and social cohesion. This has meant that research on the children of immigrants often focuses on questions of identity and belonging based on

1 Previous population flows from Equatorial Guinea are distinguished by a stronger link to colonial relations and by political and educational migration and, to a lesser extent, labor migration (Aixelà 2012). The population of black slave descent, not estimated due to the lack of an official census, should be added.

2 Spain has the highest gap in early school leaving and other educational indicators between native students and the children of immigrants in the European Union (Carrasco et al. 2018). 
the ethnic border (Anthias 2009; Yuval-Davis et al. 2006). Critical intersectional theory has questioned this approach by overstating a single aspect of collective identification, as well as the methodological dangers involved in it.

Most definitions understand intersectionality (Crenshaw 1989) as an epistemology centered on narratives about the processes of subjectivity of the gendered, racialized, classed, sexualized and colonized "others", including religious identity among other categories of difference, and make visible how hegemonic forms of power constitute and impact on everyday life experiences, while responding to them (Brah and Phoenix 2004; Mirza 2008; Phoenix and Pattynama 2006). These processes are changing and interrelated with the historical and geographical context, the process of "being and becoming" (Mirza 2008) or the analysis of "lived life" (Mirza 2013). In each case, it is necessary to identify the lines along which differences are created that become relevant to the particular experience and although they are intertwined, they cannot be treated in the same way (Lombardo and Verloo 2010) or reduced to each other (Yuval-Davis 2006). They are not additions, as in the additive models of Marxist feminism, but each division is constitutive in intersection with another, so that "social class is always gendered and racialised, gender is always classed and racialised, and so on" (Anthias 2009, p. 10)

How can this epistemology contribute to the study of the processes of social incorporation experienced by the children of immigrants in Europe? The contributions of the British intersectional perspective, and specifically the concepts of Floya Anthias and Nira Yuval-Davis about the processes of collective identification, citizenship and belonging can help to operationalize the analysis. Anthias $(2002,2009)$, argued that the study of collective identification processes had overemphasized ethnic issues, even though people do not make links solely in these terms, but through other social relations and categories such as gender, age or life cycle, social class, political beliefs and values, among others.

According to this author, the concept of identity questions "too much and too little" by asking subjects to explain coherently who they are and what and who they identify with, while forgetting aspects of structure and context. The notion of multiple identities reproduces this problem. To overcome this approach, she proposed the concept of "translocational positionality" (Anthias 2002, 2009) as a methodological tool.

Narratives about location and positionality are more useful for analyzing the processes and results of collective identification than a concept of unitary identity that reduces difference and inequality to individual characteristics. Paying attention to the location and not to the group helps to contextualize the system of social stratification and the forms of inclusion and exclusion, even if they are not conscious elements or do not produce an identity. Focusing on "positionality" combines an element of social position resulting from intersection (outcome) and positioning through a set of practices, actions and meanings (process), that is, both the impact of the social structure and the individual agency. The term translocated suggests the concept of diasporic identity as a hybridization and reflects the complexity of the positionality of subjects in the interaction of locations and dislocations of gender, ethnicity, nationality, belonging, class and racialization. This concept allows to privilege the formation of specific categories (e.g., gender or class) at a conjunctural and non-essentialist or a priori level.

Yuval-Davis (2006) insisted on the need to distinguish between belonging and politics of belonging, defining the different analytical levels of each concept. Through the analysis of the British context, this author shows how discourses on belonging tend to be constructed with respect to specific projects which select only a few levels to support their arguments. In particular, in Yuval-Davis' work, belonging is defined as an emotional bond that can be multiple and vary over time. An act of self-identification or identification by others, elaborated in a dynamic process. It includes both identifications and emotional ties as well as social positions and ethical systems and political values that judge membership. Emotional constructions of individual and collective identities and attachments, or the desire for them, work to project a future path, but this belonging to a group implies a location in the power axes of society. Include both the way in which these locations 
and identifications are judged and valued, and the attitudes and ideology upon which categories and boundaries are drawn, in a more permeable or exclusive way.

Instead, politics of belonging are ethical and ideological contestations to maintain and reproduce the boundaries that define the community of belonging by hegemonic powers or other agents. Social positions and narratives on identity are usually presented as elements of emotional bonding, in an essentialist and racialized way, hiding the role of the axes of power and privilege. On the contrary, referring only to social positions would also forget the importance of the elements of emotional bonding and hide the fact that constructions about one's identity, as Fanon (1952) showed in his classical work, have sometimes been generated in processes of forced internalization.

According to the same author, it is relevant to differentiate two levels in the politics of belonging: Citizenship and rights and status, which are not always correlated. Although in the global world the lives of individuals are constituted with rights and obligations in the local, ethnic, religious, national, regional, transnational and international context, in a simultaneous and interconnected way, citizenship continues to be understood closely, as the relationships of rights and obligations that individuals and/or communities establish with the nation-state.

However, formal citizenship does not imply actually belonging to the nation-state community for those constructed as others (whether ethnic, racial or national others), (Yuval-Davis 2007). In different projects of belonging, the characteristics that define it can become requirements, ranging from social positions (origin, place of birth or ethnic group), those that are less permeable and more racialized, to cultural aspects such as language or religion, accessible by assimilation, or apparently permeable borders, such as values such as democracy or human rights. These three levels can overlap in specific cases and are often presented in a more open way than they really imply. An example is the migration and membership policy of the British context of liberal multiculturalism and social cohesion, analyzed by Yuval-Davis et al. (2006), in which the defense of civic and democratic values is not only a marker of identity but also an argument for defending the "civilising mission" carried out by the United Kingdom and the USA and extended to other European countries, including Spain. This apparently progressive policy, in contrast to the discourses of the right-wing or the assimilationist perspective, understands integration in a unidirectional way on the part of migrants and holds them responsible for the lack of social cohesion, resulting in equal exclusion.

This theoretical framework will allow, in the following sections, to complicate the debate from ethnic identifications and borders to the impact of social positions and agency, in a contextualized way.

\section{Method}

This paper is based on a multilevel (Ogbu 1981) and narrative (Ellis 2004) ethnography, focusing on the life and academic trajectories and experiences of a group of young people, children of immigrants from West Africa, in processes towards adulthood. Fieldwork was carried out in the region of Barcelona where their presence is over-represented (according to data from the local census, in 2016, these nationalities represented $20.8 \%$ of the foreign population, over the average in Catalonia). The author has prior personal and professional experience of collaboration with the Black African organizations and families of the area who had expressed concerns about their children's risk of exclusion in the Catalan society. As an outsider, adult woman, the researcher displayed several strategies to ensure ethic relations with the subjects, trying to enhance common positions and experiences with the young women, for example, motherhood or schooling. The research has focused on two groups of young people at different stages of transition to adult independent life, young-adolescents and young-adults, selected through a snowball strategy.

This article uses part of the biographical reconstructions elaborated with a counternarrative objective (Solórzano and Yosso 2002), through various interviews carried out over three years in the group of young adult woman (17-24 years old), from eight families 
belonging to the flow of ethnic communities (Jabardo 2006), This approach has been complemented by the analysis of their public profiles on social networks and interviews with some of the parents, as well as participant observation in family and community events and interviews with different members of Black African associations.

The data analysis has been carried out with the qualitative analysis software Nvivo. All the material has been transcribed, coded in two phases, first thematically and second, compared through the program visual tools, case classifications and matrix analysis. Special importance was given to the emotional climate that emerged in the interviews themselves and the stories constructed by the young women (Mattingly and Lawlor 2000).

The recurrent typological variety identified in the fieldwork is illustrated in Table 1 and in the text through the analysis of the narratives of six girls born in Catalonia, Spain, to Gambian and Senegalese parents, all of them naturalized, and belonging to working class families in low skill jobs in the destination country. All of them define themselves as Muslims, none of them wear a veil, all dress in the Western style and usually speak Spanish with their peers, even though they are competent in Catalan mostly through schooling and despite the fact that their parents insist on maintaining the family language.

Table 1. Main socio-demographic data.

\begin{tabular}{|c|c|c|c|c|c|c|c|}
\hline & Age * & $\begin{array}{l}\text { Ethnic } \\
\text { Group }\end{array}$ & $\begin{array}{c}\text { Parents' Place of } \\
\text { Birth }\end{array}$ & $\begin{array}{l}\text { Parents' Job (or Tutors } \\
\text { or Heads of } \\
\text { Household) }\end{array}$ & $\begin{array}{l}\text { Marital } \\
\text { Status }\end{array}$ & $\begin{array}{l}\text { Residential Pattern } \\
\text { and Number of } \\
\text { People in the } \\
\text { Household }\end{array}$ & $\begin{array}{l}\text { Number of } \\
\text { Children }\end{array}$ \\
\hline $\begin{array}{l}\text { Case 01: } \\
\text { Adama }\end{array}$ & $19-23$ & Fula & $\begin{array}{l}\text { The Gambia } \\
\text { Rural area }\end{array}$ & $\begin{array}{l}\text { Hotel gardener (father) } \\
\text { and hotel cleaner } \\
\text { (mother) }\end{array}$ & Single & $\begin{array}{c}\text { Dependent } \\
7 \text { (Father, mother and } \\
4 \text { siblings) }\end{array}$ & 0 \\
\hline Case 02: Fatou & $17-20$ & Fula & $\begin{array}{l}\text { The Gambia } \\
\text { Rural area }\end{array}$ & $\begin{array}{c}\text { Factory operator } \\
\text { (father), hotel cleaning } \\
\text { (mother) }\end{array}$ & Single & $\begin{array}{c}\text { Dependent } \\
7 \text { (Father, mother and } \\
4 \text { siblings) }\end{array}$ & 0 \\
\hline Case 03: Isatou & $24-26$ & Fula & $\begin{array}{c}\text { Senegal } \\
\text { Rural area }\end{array}$ & $\begin{array}{l}\text { Unemployed (cleaning) } \\
\text { and kitchen manager } \\
\text { (husband) } \\
\text { /mechanic (father); } \\
\text { cleaning (mother) and } \\
\text { geriatric assistant } \\
\text { (father's wife) }\end{array}$ & Married & $\begin{array}{c}\text { Independent } \\
5 \text { (Husband, } 2 \\
\text { children and } 1 \text { sister) }\end{array}$ & 2 \\
\hline $\begin{array}{l}\text { Case 04: } \\
\text { Maimuna }\end{array}$ & $17-20$ & Sarahule & $\begin{array}{l}\text { Senegal (father); The } \\
\text { Gambia (mother), } \\
\text { (both rural areas) }\end{array}$ & $\begin{array}{l}\text { Self-employed trader } \\
\text { (father), kitchen } \\
\text { assistant (mother), } \\
\text { housework } \\
\text { (father's wife) }\end{array}$ & Single & $\begin{array}{c}\text { Dependent } \\
15 \text { (Father, mother, } \\
\text { father's first wife, } 11 \\
\text { brothers and sisters) }\end{array}$ & 0 \\
\hline $\begin{array}{l}\text { Case 05: } \\
\text { Mariama }\end{array}$ & $19-23$ & Fula & $\begin{array}{l}\text { Senegal (father, rural } \\
\text { area; mother } \\
\text { urban area) }\end{array}$ & $\begin{array}{l}\text { Unemployed (last } \\
\text { job carrier) }\end{array}$ & Single & $\begin{array}{c}\text { Dependent } \\
7 \text { (Uncles, } 3 \text { cousins } \\
\text { and } 1 \text { brother) }\end{array}$ & 0 \\
\hline Case 06: Sayo & $19-21$ & Fula & $\begin{array}{l}\text { Senegal } \\
\text { Rural area }\end{array}$ & $\begin{array}{l}\text { Unemployed/Retired } \\
\text { gardener (grandfather), } \\
\text { geriàtric assitants } \\
\text { ( } 2 \text { wives of } \\
\text { grandfather) }\end{array}$ & Single & $\begin{array}{c}\text { Independent } \\
2 \text { (She and her son) }\end{array}$ & 1 \\
\hline
\end{tabular}

(*) Age at the first and last interview.

\section{Results}

The academic trajectories and the level of education achieved are described below, creating two groups based on the threshold set by the Europe 2020 strategy as the minimum to guarantee the labor and social inclusion of EU citizens (post-compulsory secondary education, or being in education or training to achieve it). This will provide a picture of the tools with which they face their transitions into adulthood, clearly divided into young women who left school and training early versus young women with post-compulsory education continuity 


\subsection{Prolonged Trajectories and Insurmountable Barriers}

The trajectories of the young women of this group have been characterized by school dropouts in the transition to secondary education and their experience shows a clear lack of support to facilitate their return to the educational system.

Isatou is 26 years old and unemployed. She lives with her husband (kitchen manager), two children and her sister in a city on the outskirts of Barcelona, in a neighborhood with a high concentration of third country nationals. During her childhood and adolescence, she lived in the area where the ethnography took place, with her father (a pioneer and promoter of an association of Senegalese), her mother, her father's first wife and seven brothers and sisters. Her academic career ended early, although she was considered a good student in primary school. After completing five years of secondary education in a public high school, she did not manage to graduate. According to her, exclusion by her classmates made her relate to "bad company" by starting nightlife early and avoiding the limitations of her parents who told her "to study, that she would have time to go out". Although she would like to become a hairdresser, she currently has no plans towards that goal.

Sayo is 21 years old and lives in a city in the Maresme region with her year and a half old son in a social flat provided by the Social Services. She spent her childhood and adolescence in the care of her maternal grandfather, living with his two wives and three children each, after her mother died when she was 4 years old and having spent some time in a foster home. She did all her schooling in public schools. From being a very good student in primary school she went on to "become lazy" in secondary school and repeated twice until she left Secondary Education in the second year at the age of 16. Later she started a training which she did not finish because of a trip to Senegal, and the same thing happened with the course to get the compulsory secondary education certificate in an adult school, in a second trip to which she was dragged by her grandfather, abandoning the idea of continuing her studies. She met the father of her son, who was born in Senegal and arrived in Spain as an unaccompanied minor, when she was going out in Barcelona with her friends, all Black African, and although they do not live together due to their irregular situation and his activities, they keep in touch. Her current objective is to find a job to support herself and her son.

\subsection{Adjusted Path: Vocational Training Itineraries}

The young women in this group opted for the vocational training route, guided by the teachers and, in two cases, to the disappointment of their families. While for some obtaining a profession was the objective, for others it was a narrow aspiration and their path became a long-distance race.

Maimuna is a 19-year-old girl who works as a geriatric assistant (chaining short-term contracts in different companies) after having studied a Vocational Education and Training (ISCED 3) of social and health care and lives with her family (father, mother, father's first wife and siblings). Her peer group is the girls she plays basketball with (all white, from lower-middle class or working-class families). After spending her early childhood in Valencia with an aunt, she returned to her parents and started school. She had to try to overcome the shyness that, according to her, limited her and that led her to a reinforcement group until fourth grade of primary school. Finally, she got the Secondary education certificate in an ordinary group, a great success being the first in her family to achieve it. Her wish was to be incorporated into the labor market at an early age and so she thought of a profession through vocational training. Although she fulfilled her objective, she began to realize that it did not allow her to combat precariousness and temporary work.

Fatou is 19 years old, she is in a Vocational Training of social integration and working as a geriatric assistant in an old people's home. She lives with her parents and siblings. Her school experiences have been tinged with the impact she has had in embodying "the difference", feeling out of place in a Christian private school (state-funded) in primary education, and suffering bullying in the first years of Secondary education in a public high school. Her school performance was medium-high, but "for fear of failure" and 
disappointed her parents who want her "not to have a bad time like them", she decided to take a longer route (vocational training) to fulfil her academic aspirations and reach higher education. She keeps a friend from high school, "her white friend", as she says, but increasingly relates to a group of boys and girls who are all children of immigrants from West Africa.

Mariama is 21 years old. She now lives with her father's family and her younger brother in France and is studying at university. She was born in Catalonia, the daughter of Senegalese parents of Fula ethnicity, but decided to leave once she graduated from Vocational training in search of greater educational and employment opportunities. Although her family was originally from the middle classes, in Spain her parents held low-skilled jobs (father a transport worker and mother a nurse's assistant and kitchen assistant in hotels), both of whom are currently unemployed, being one of the families affected by mortgage debt and having been divorced. During her childhood she lived in a town in French Provence, where she spent part of her schooling. In contrast to her schooling experience in Spain, she had the support of her teachers, her cousins and an organized "school-to-home" life that offered her the supervision of her extended family, who were well off in France and not in the initial phase of incorporation, like her parents in Spain. Her return meant a repeat of the course and a lowering of her aspirations, being oriented to vocational training, which she attended and certificated, although it was not satisfactory for her.

\subsection{A Path of Naturalised Progress: Academic Itinerary, Moving Smoothly towards Higher Education}

The young woman who exemplifies this typology is characterized by academic achievement and direct transitions, following the most prestigious itineraries. It can be said that this more successful path has been an exception among the cases encountered during the field work.

Adama is 22 years old and lives with her parents and four siblings, all students. Currently, about to graduate in psychology, she has never been in the working world. Her academic career is known among the young children of Gambians and Senegalese in her area, as she is a pioneer and a reference, although at school her success was either unnoticed or surprisingly exceptional. Her parents, who belonged to a prestigious family in her home village, always had high expectations of her, sending her messages of academic achievement as well as reinforcing her intra-ethnic identity. Her friends (all white middle class) were also a great support.

The itineraries and experiences described above show, first of all, the risk of social exclusion faced by young women who left education and training early, without mechanisms to encourage them to change their situation. However, secondly, a range of successful trajectories emerges that are invisible in the face of a widespread idea of failure or early leaving among this group of children of immigrants. In some cases, these are short-lived trajectories that raise other notions of success; in others, long-distance careers with greater risks of abandonment, and, finally, itineraries and experiences associated with the notion of hegemonic notions of success.

\section{Ties of Belonging and Collective Identification Processes}

We will then focus on some key aspects to assess the ties related to belonging and the processes of collective identification: Emotional identifications, social positions and gender values and ideologies, in order to answer the question about which lines of difference emerge as relevant and how they impacted on their daily experience.

It is clear that their narratives contrast with the main social representations, which project a retrograde community and young women subjected to tradition. In contrast, the agency of these women in confronting the patriarchal forms of power that emerge in the community is shown, as well as the racialization experienced in the contact spaces with the majority population. 


\subsection{Embodying Difference and the Collective: Social Positions}

A common element among these young women is how the intersection between racialization and social class is transferred into their daily lives in the form of discomfort, exclusion, loneliness and insecurity.

They recalled episodes in which the difference in which they were placed was built up from negative stereotypes, associating blackness, foreigners and poverty. An example of this is the disengagement that Fatou described in the primary school (subsidized school assigned by the desegregation policy of balanced schooling) ${ }^{3}$ in contrast to the well-being she felt in the "Centre Obert" (an after-school socio-educational service offered by local social services) where the children belonged to the same social class and many were Black African, the children of immigrants: "I felt good ( . . ) I understood them better. I understood them better. There were so many of them" (Fatou).

Similarly, Isatou told how she felt excluded at the high school (also a subsidized center, assigned by the same policy) and was mocked and commented on as a non-national, but above all for being built up as a poor person. She recalled how on one occasion her wallet was taken away to show the rest of the class how she did not have an ID card like the others, how she noticed gossip about her clothes or the frequent questions about whether they paid for school. The cause she attributes to this experience of discrimination once again suggests the construction of an inverse relationship between racialization and social class: "Because I was Black, and they were all posh there" (Isatou). Moreover, while most deny racism, many have perceived gossip, especially in schools. This is how Mariama summed it up: “It's just that the Moroccans and the Black people here, I don't know what ... they come here for this and that and smell like that, you know? and I was left listening ... I think they beat up the Moroccans a bit more, but we Black people are always in there" (Mariama).

This reminder of the difference was also constructed from "positive" stereotypes, such as compliments on their hair, color, curves or the rhythm of "las negras" (the blacks) so that their presence embodied not only their person but also a whole "group" in which they were located, based on their phenotype from which cultural racism was constructed, and dislocated from belonging to the "we". This also happened with supposedly neutral questions about their family customs (food, polygyny, etc.) or other cultural elements, to which some girls expressed their discomfort that in some cases, like Isatou's, embarrassed her to the point of making her avoid the presence of other Black people. Another way in which they felt this location in the otherness, was evidencing the surprise that their behavior caused by opposing the expected. Adama remembers that "If I did something right it was like, 'Oh, good', but it was like ... I was flattered more just because I did it right, I don't know ... like they underestimated me."

Finally, through explicit comments that denoted the association of their phenotype with the foreigner. From statements that referred to "their country" to congratulations for a supposed assimilation. For example, when strangers spontaneously address them with a "you're from here, eh!" if they hear them speaking Catalan, while they abandon the idea of continually explaining that they were born "here". Clearly the black phenotype emerges above the competence of the language as a marker of non-belonging, being stripped in a supposedly positive commentary of the status and rights that citizenship entails. So, in a way, it cannot be just them, but their presence represents the whole of young Black women. Faced with this, they develop different strategies that range from ignorance "passing", to avoidance, shaping their personality or hiding their way of being, not without emotional impact, or even, as explained by the girls who suffered most constantly and explicitly from discrimination by their peers, with violent reactions, "making themselves respected" or "defending themselves and taking out their character". In the words of Fatou: "Every time I said something to myself, I would shut up, I would scold myself, you know? I once had a problem with a child because he was always bothering me and I got angry, I grabbed him

There are two types of schools: privately owned but State-funded ones and públic ones. 
by the neck and I pulled him up against-I wanted him-I was already fed up with him, he always came home crying, why didn't they stop!".

They also told of other strategies that originated not from specific episodes but from having developed, over the years, an awareness of racialization and the embodiment of the difference it makes. This has caused some girls to avoid relationships with non-black youth. Isatou recalled this personal process and that of other girls: "Bintu left her white circle of friends and I left it too and we Black girls got together. And we said to each other we are very good, very good".

In some cases, all this had an impact on their self-perception as students and, although some obtained good results during their schooling, they did not feel capable of following the most valued academic paths-the Baccalaureate and/or the university—becoming aware of the difficulty of accessing prestigious professions even if they have a degree to do so. In this way, the emigration of the children of Black African immigrants can be considered a strategy to confront the experienced racism that many of the young women fantasize about, and that others have done or have acquaintances who have done so:

"Everyone gets bored here. I would go to France if I could. You have more opportunities there. Even if they say no, there is a little bit of racism. There you get the title of what you want and you work in that sector. Here my cousins have studied and they don't work from that. One is a nurse, went to university and everything. The other did a higher degree in administration and then university; another, tourism; none of them is working at what they want, or as a waitress or cleaner ( ... ) it's the fact of being Black". (Isatou)

\subsection{Negotiating Intergenerational Boundaries: Gender Values and Ideologies}

Most girls felt that their fathers' generation had become more Muslim. They did not remember their fathers praying, nor that their mothers wore veils when they were young, nor that they supervised whether or not they performed the prayers, in a possible process of ethnic withdrawal (Moreras 2006). Nonetheless, beyond the religious aspect, some young women showed frustration with ideals about children based on maintaining tradition, for example through knowledge of the mother tongue, or on marriage as an institution for building the family. Adama and Isatou expressed it this way:

"She should listen to her parents, help out around the house and so on, and about traditions ... like- "Look how well the daughter talks about this or that, she talks perfectly ( ... ) it made me feel bad, like I don't know how to talk well!". (Adama)

"Sidy Saho's daughter had given birth a month ago. My father was "-Uuuh, look! Did you see? She has to leave school now ... I hope that at least you will leave until you get married ...". (Isatou)

Although in its traditional definition marriage place them in a subordinate position with respect to the men of their generation, it should be noted that the main arguments used by parents were precisely messages that valued education, although they did not conceive of the compatibility of both spheres: Studying and forming a family. On the other hand, although the rule is clear, failure to comply with it has not always been penalized, and for example in the case of Isatou, his father celebrated being a grandfather and "called everyone".

In the face of this, all the young women resisted these locations by opposing the preferential marriage forms: In the most traditional definition, marriage with the crossed cousins; and more widespread in migration, marriage agreed with fictitious relatives: The son of a friend of the father (whom they call an uncle). However, most families have abandoned the idea of maintaining the practice of an agreed marriage without the consent of their daughters, even if they put forward their preferences, such as the bond with fictitious relatives: 
"Yes, they want me to marry the son of one of my father's friends, and they've told me about it and ... I'm not too happy about it either, am I? Because I don't know, it's a bit like telling me what to do". (Adama)

Or, with whomever they choose, provided that he is a Muslim:

"My father there is a little bit more ... if I have to marry someone who is a Muslim, to continue being ... not to lose ... because if I marry a white man, because I am a girl I would lose my religion and ... I would cling more to my partner's religion". (Mariama)

Even one of the girls (Maimuna) who refers to having a "very traditional", "very religious" father, states that she would oppose an arranged marriage, especially early on, and develops different forms of resistance (hiding practices that the father would consider inappropriate, such as going to the beach or having a boyfriend) with the help of her mother, who considers that she should "act like here, since she was born here". However, this pressure to comply with a gender and age model that she feels oppressive has not limited her academic career or social relations. She herself gave the example of her refusal to participate in school camps, although it could be assumed that it was for economic reasons or because of her father's strict control attitude, it was she who did not want to be away from her family. Her father did not deal with school issues, a role assumed by her mother (as is the case in economies with a clear division of reproductive labor), so he did not have a limiting role either. "My father didn't pay much attention. It was my mother who paid. She paid for the outings...".

While some young people, provided they had the capacity to decide, considered valuing family opinions, such as Mariama, who reflected on the difficulties a non-Muslim husband can have in maintaining practices such as holding Ramadan, there are other issues that were strongly opposed by all, and clearly one of them is polygyny, a type of marriage that is not in the majority but is an element of social distinction between previous generations.

“That the husband has many women, that seems to me, I don't know, this makes me very angry, it doesn't seem right to me. Maybe they accept it. Look at the case of African women who marry out of obligation, have children, but are not in love, they have to be there for the children. These women suffer too, and nobody listens to them". (Fatou)

A significant case is that of Adama's family, who lived through their father's "temporary" polygamy with such bewilderment thatforced the father to divorce his second wife soon after, an example she recounted with awe.

In the discourse of these young women, it is usually valued that their parents have developed a negotiating style of upbringing, agreeing on aspects such as the times of departure, and many consider themselves lucky not to have a father or mother who is "as closed" as other Muslims. Gender roles in most families have also become more flexible, with men, for example, carrying out household tasks, although not in a corresponding way, even though they continue to assume more household responsibilities than their brothers. In short, while they are pressured to represent family prestige, maintaining sexual honor (and other practices associated with cultural non-assimilation, such as maintaining the family language or identifying themselves as Muslims), they respond to this by negotiating what they see as boundaries with the previous generation.

\subsection{Fitting in with Modernity: Main Emotional Identifications}

In relation to emotional identifications, gender emerges as a key element for the experience of blackness. It becomes a central aspect of positionality and belonging, but not independently but in intersection with other variables, in this case, racialization, that is, the social construction of difference based on skin color, as well as age or generation: The set of young Black girls. 
Firstly, the girls' narratives show a lack of identification with Black boys. In contexts where there are no other young Black women they feel "the only one". This feeling of uniqueness, of otherness, is common to all the stories, especially when they refer to the academic world. Adama described it this way: "I was the only Black woman in class, a girl, the others were Black boys, and well ... little by little I adapted. My mother said at the beginning.--Isn't there more like you ... ? And I said:-it's just me in class," said Maimuna, or "When I've been around campus and seen other Black girls it's like, there are more people! I' $m$ not the only one! In the same way, they also distinguish themselves from women of the previous generation in many ways and even go so far as to construct a stereotype about them or what women in West Africa are like: 'close-minded' Muslims" (Fatou), "very covered" (Maimuna) or considering themselves "more European" than the "typical Black African" (Mariama).

Secondly, all the young women except Sayo explained that they considered themselves to be Muslims, but that they intended to be able to know their religion better (e.g., recite the Koran with knowledge of its content) in order to be able to discern what they thought was appropriate or not. This critical approach allowed them to decide not to wear a veil or to consider arranged marriage or polygyny unacceptable. For this reason, some say they consider themselves "less" Muslim than their parents (now, not when they were little), although some attended weekly Koranic classes. Furthermore, one of the girls, Isatou, explained how she was fascinated by a new view of the family culture given to her by her husband, an immigrant of Senegalese origin, which she did not know, and by an approach to religion that her family had not taught her. Specifically, she referred to the initiatory, productive and contemplative side of Islam practiced by the Murid diaspora, which I recognized from a large poster on the wall as the only decoration in her house: "I saw them praying, they were with the book of the Koran [with a fascinated voice], if I loved it, they told us the stories and I liked it a lot".

In general, many argued paradoxically, "I don't know much about my culture" (Fatou). While they let the emotional identification with the family culture or, as Maimuna said, "their country", rectifying at once to say "the country of my parents", they assert a great lack of knowledge that does not allow them to identify fully either. Adama, for example, describes a situational identification. "When I am at home for example I feel more Gambian, I don't know, when I am with friends I feel more Spanish" or Mariama, who explains how she was only defined as Spanish when she was in France "they always called me the Spanish one".

Thirdly, their ethnic identification was undefined and they narrated it full of nuances, highlighting for example their place of birth, or desisting from elaborating a geographically located belonging: "I have not been made to feel from here, from situations of the past ... nor from there, why I do not know it" (Fatou).

Finally, it is revealing to analyze their future projections as significant elements in emotional identifications. All the young women projected themselves as mothers and wives, without questioning marriage (from a position critical of tradition) or motherhood (which they pose in the long term and with fewer children than their families). At the same time, some of them prioritize developing their high professional aspirations and emancipating themselves as independent women (Adama, psychologist; Mariama, translator/interpreter; Fatou, child educator or social integrator). Although, in general, their stories show a lack of models or references in this aspect, being themselves the pioneers in their environments. Only the girls who have experienced mobility describe models of women in which they are reflected: A "modern African woman", says Mariama, repeating the hegemonic discourse based on a dichotomous identity: Either African or European, linked respectively to tradition or modernity:

"I, my aunt there, she is very modern, very ... related to the parents of ... because here the whites always relate a lot to their children's parents when they go to school. But here ... I've hardly seen any Black women who go and perhaps relate to the parents of ..." ". (Mariama) 
Another part of the young women aspires to a professional life that provides them with agency and independence "to help out around the house, or when I have my own house, to put things in," says Maimuna, (reproducing the role expected of an adult woman in West Africa) and within this logic they limit their aspirations. For example, in the case of Isatou, who would like to be a hairdresser, or Maimuna, who would like to be a nurse: One gave up and the other adapted it to being a geriatric assistant, prioritizing a quick incorporation into the labor market and considering that extending the education years would be "a waste of time" (Sayo) or "a waste of more time" (Maimuna).

\section{Conditions for Emancipation: Resituating Responsibilities}

This work reveals the importance of an intersectional approach for the analysis of the processes of belonging of young Black women in Europe. The experiences presented and the analysis used add evidence about the nuances of the replications of assimilation theories coming from the American context in Europe. As Crul and Schneider (2013) pointed out, in the European context, both patterns of downward assimilation and upward mobility through intra-ethnic cohesion can occur within the same group or ethnic community. In the above case, this diversity translates into different conditions for emancipation. Transition paths to adulthood based on rapid incorporation into the labor market or on motherhood show a reproduction of the social position occupied by women of the previous generation (migrants without academic training). It is not possible to explain this situation solely by a "more" patriarchal intra-community system, of which young women do not feel fully a part and of which some aspects are resistant, but to which young women with long and successful academic careers have also been subjected, which should make upward social mobility possible. In contrast, the experiences of educational continuity show the importance of the cultural capital provided by education as "emancipatory capital". This expands the tools to combat hegemonic racialized positions, conditioned by class and gender, which place these young women in subordinate positions, not without them finding the gaps to be able to develop their projects.

In the cases analyzed, although the young women's families insist on transmitting specific ethical and moral values to define femininity based on a patriarchal system, these discourses coexist with high educational expectations. We can identify in their narratives recurrent themes in the literature on minority youth and gender. For example, the increased domestic responsibilities and parental control in relation to male peers, which SuárezOrozco and Qin (2006) interpreted as an intensification carried out by families in the face of the danger of assimilation, with sexual honor being a key indicator that establishes their prestige in the community in the transnational context. Or, as Espiritu (2001) pointed out, a display of moral superiority in the face of Western culture, responding to the subordination and stereotypes that hypersexualized "other" women.

Issues such as polygyny and arranged marriages emerge as symbolic boundaries with respect to the previous generation, revealing the resistance of young women to central aspects of traditional gender ideology that can lead to intergenerational conflict. However, these messages coexist with other egalitarians, which were realized especially by the mothers, transferring their desire for more equitable relations, in the same way as had been observed in the case of young Roma women with successful educational careers (Abajo and Carrasco 2004; Bereményi and Carrasco 2017).

Thus, the counter-narrative that emerges from the stories paradoxically gives a leading role to the school environment which, as Carter (2005) argued, systematically ignores and devalues non-dominant forms of cultural capital, demanding conformity with the dominant white $^{4}$ and middle class culture. Now, what impact does this have on the academic and life trajectories of young women? Firstly, as Archer (2008) identified in the British context where discourses about the "ideal student" excluded minority students, some young women

4 Although racial ideology based on black/white dualism is not applicable to the Spanish context, racial categories are present in social discourses (e.g., "negro" or "negrito") and "Spanish" national identity has been racialized as synonymous with European origin and whiteness (Banton, quoted in Keaton 2005). 
integrated a limited self-perception of the student. This is clearly the case of young women with ELET, but it is relevant for those who, with good performance, did not conceive of following the paths built as successful, nor were they oriented towards it. Although it could be considered a pragmatic decision (Mirza 1992), adapting their aspirations to the awareness of the unequal opportunities they find in the labor market, as well as, from this same logic, some propose their own migration projects, mobilizing the migration capital they have (Narciso and Carrasco 2017).

Secondly, an impact on the processes of subjectivation, as indicated by studies of post-colonial feminism. Racialized subjects and minority and working-class women do not manage to see themselves as appropriate, they are constructed in a devalued way, with inadequate females, generating painful processes that reproduce colonial relations, and placing them in a continuum of normalized absence/pathologized presence. In the face of this, some young women become "ashamed" and choose to avoid affiliation with members of their own group, or they shape themselves by trying to achieve academic success, which from the ecological-cultural theory was defined as "acting white", or in the opposite sense, as some girls explained, they "act out" with definitions of femininity that do not fit in with those promoted by the school (less docile) and/or choose the alliance with their peers in more protective relationships by assuming the academic risk that may be involved (Archer-Banks and Behar-Horenstein 2011; Fordham 1993, 2008). As we have seen, these processes are not exclusive and are transformed over time.

Finally, the desire to project themselves as modern women is identified, distancing themselves from the women of the previous generation and the migrants of their family origin, over whom they have internalized the hegemonic stereotypes and the supremacist discourse that hierarchically dichotomizes "us/them" with an image of West Africa that does not recognize its cosmopolitanism and defines it in an atavistic way, in the same way as Muslim membership. The new constructions of Islam, to which some feel affiliated, offer them a certain authority and grounds for rejecting traditional practices without appearing excessively "westernised", as Ryan (2013) showed in the case of young Muslims in London, and can be interpreted as processes of additive acculturation (Gibson 1988). They clearly associate modernity with freedom, inter-community relations and the development of professional life, assuming hegemonic gender definitions that include public/private and production/reproduction dichotomies. Moreover, their break with aspects such as polygyny also deprives them of the feminine space that characterizes the sex/gender system in West Africa and which Jabardo and Ródenas (2017) define under the rules of cooperation and competitiveness, and which migrant women "both accept and challenge, in processes of hybridisation that reflect the emergence of other, new modernities". This implies, for example, that among these young women there are no institutionalized forms of horizontal social capital, such as the female associative practices of the generation itself, which their mothers did have, in a possible subtractive process, similar to that described by Valenzuela (1999), pointing to school, and which is reminiscent of the situation that Keaton (2005) showed in the case of young Black African women in France, where school was key to assimilating and at the same time excluding these young women.

In conclusion, in this article I have tried to show how the limits of social inclusion in their processes to adulthood life of these young women are produced mainly by the racialization experienced, intertwined with social class and gender, paradoxically in key spaces of social inclusion, such as the school and the labor market, and not by an ethnic community that subjugates them. This idea derives from the politics of racialized belonging, although it avoids racial-biological labels, rhetorically maintains national-ethnic categories, ultimately considers difference a threat, and while it promotes assimilation it perpetuates forms of social exclusion.

Funding: This research has received funding from the European Union's Seventh Framework Programme for research, technological development and demonstration under grant agreement no 320223. The content of this publication represents the views of the authors only and is their sole 
responsibility. The European Commission does not accept any responsibility for use that may be made of the information it contains.

Institutional Review Board Statement: Not applicable.

Informed Consent Statement: Informed consent was obtained from all subjects involved in the study.

Data Availability Statement: Author's custody, available on demand.

Conflicts of Interest: The author declares no conflict of interest.

\section{References}

Abajo, José E., and Sílvia Carrasco. 2004. Experiencias y trayectorias de éxito escolar de gitanas y gitanos en España. Colección Mujeres en la Educación, 4. Madrid: CIDE-Instituto de la Mujer.

Aixelà, Yolanda. 2012. Entre las dictaduras y el petróleo: Las migraciones transnacionales de Guinea Ecuatorial. Revista Andaluza de Antropología 3: 80-93. [CrossRef]

Alba, Richard. 2005. Bright vs. Blurred Boundaries: Second-generation Assimilation and Exclusion in France, Germany and the United States. Ethnic and Racial Studies. [CrossRef]

Anthias, Floya. 2002. Where Do I Belong? Narrating Collective Identity and Translocational Positionality. Ethnicities. [CrossRef]

Anthias, Floya. 2009. Translocational Belonging, Identity and Generation: Questions and Problems in Migration and Ethnic Studies. Finnish Journal of Ethnicity and Migration 4: 6-15.

Archer, Louise. 2008. The Impossibility of Minority Ethnic Educational 'Success'? An Examination of the Discourses of Teachers. European Educational Research Journal. [CrossRef]

Archer-Banks, Diane M., and Linda S. Behar-Horenstein. 2011. Ogbu Revisited: Unpacking High-Achieving African American Girls' High School Experiences. Urban Education 47: 198-223. [CrossRef]

Barth, Fredrik, ed. 1998. Ethnic Groups and Boundaries: The Social Organization of Cultural Difference. Long Grove: Waveland Press. First published 1969.

Bereményi, B. Ábel, and Sílvia Carrasco. 2017. Bittersweet Success. The Impact of Academic Achievement among the Spanish Roma after a Decade of Roma Inclusion. In Second International Handbook of Urban Education. New York: Springer International Handbooks of Education, pp. 1169-98.

Brah, Avtar, and Ann Phoenix. 2004. Ain' T I A Woman? Revisiting Intersectionality. Journal of International Women's Studies 5: 75-86.

Carrasco, Sílvia, Jordi Pàmies, and Laia Narciso. 2018. Abandono escolar prematuro y alumnado de origen extranjero en España ¿Un problema invisible? Anuario CIDOB de la Inmigración. [CrossRef]

Carter, Prudence. 2005. Keepin' It Real: School Success beyond Black and White. New York: Oxford University Press.

Crenshaw, Kimberle. 1989. Demarginalizing the Intersection of Race and Sex: A Black Feminist Critique of Antidiscrimination Doctrine, Feminist Theory and Antiracist Politics. Chicago: University of Chicago Legal Forum.

Crul, Maurice, and Jens Schneider. 2013. Second-generation migrants: Europe and the United States. In The Encyclopedia of Global Human Migration. Edited by Immanuel Ness. Hoboken: Blackwell Publishing Ltd. [CrossRef]

Ellis, Carolyn. 2004. The Ethnographic I: A Methodological Novel about Autoethnography. Walnut Creek: AltaMira Press.

Espiritu, Yen Le. 2001. We Don't Sleep around like White Girls Do: Family, Culture and Gender in Filipina American. Signs: Journal of Women in Culture and Society 26: 415-40. [CrossRef]

European Commission. 2010. Europe 2020. A European Strategy for Smart, Sustainable and Inclusive Growth. Brussels: EC.

Fanon, Frantz. 1952. Peau Noire, Masques Blancs. Paris: Seuil.

Feixa, Carles, Clara Rubio, and Joan Ganau Casas Solsona, eds. 2017. L'emigrant 2.0. Emigració juvenil, nous moviments socials i xarxes digitals. Barcelona: Generalitat de Catalunya, Dep. de Treball, Afers Socials i Famílies, Col·lecció Estudis, $\mathrm{n}^{\circ} 35$.

Fordham, Signithia. 1993. Those Loud Black Girls: (Black) Women, Silence, and Gender 'Passing' in the Academy. Anthropology E Education Quarterly 24: 3-32.

Fordham, Signithia. 2008. Beyond Capital High: On Dual Citizenship and the Strange Career of acting White. Anthropology E Education Quarterly 39: 227-46.

Gibson, Margaret A. 1988. Accommodation without Assimilation: Sikh Immigrants in an American High School. Ithaca and London: Cornell University Press.

Huntington, Samuel P. 2000. The clash of civilizations? In Culture and Politics. New York: Palgrave Macmillan, pp. 99-118.

Jabardo, Mercedes. 2006. Senegaleses en España. Conexiones entre origen y destino. Madrid (SP): Secretaría General de Inmigración y Emigración. Portal de La Inmigración, Documentos del observatorio Permanente de la Inmigración.

Jabardo, Mercedes, and Beatriz Ródenas. 2017. Más allá de las dicotomías. Un análisis de la actividad del trenzado en la diáspora senegalesa desde el Feminismo Negro. Revista Española de Sociología 26: 373-84. [CrossRef]

Keaton, Trica. 2005. Arrogant Assimilationism: National Identity Politics and African-Origin Muslim Girls in the Other France. Anthropology and Education Quarterly 36: 405-23. [CrossRef]

Kymlicka, Will. 2010. The Rise and Fall of Multiculturalism? New Debates on Inclusion and Accommodation in Diverse Societies. International Social Science Journal 61: 97-112. [CrossRef] 
Lombardo, Emanuela, and Mieke Verloo. 2010. La Interseccionalidad Del Género Con Otras Desigualdades En La Política de La Unión Europea. Revista Española de Ciencia Política 23: 11-30.

Mattingly, Cheryl, and Mary Lawlor. 2000. Learning from Stories: Narrative Interviewing in Cross-Cultural Research. Scandinavian Journal of Occupational Therapy 7: 4-14.

Mirza, Heidi S. 1992. Young, Female and Black. London and New York: Routledge.

Mirza, Heidi S. 2008. Race, Gender and Educational Desire: Why Black Women Succeed and Fail. London and New York: Routledge.

Mirza, Heidi S. 2013. A Second Skin': Embodied Intersectionality, Transnationalism and Narratives of Identity and Belonging among Muslim Women in Britain. Women's Studies International Forum 36: 5-15. [CrossRef]

Modood, Tariq, Anna Triandafyllidou, and Ricard Zapata-Barrero. 2006. Multiculturalism, Muslims and Citizenship: A European Approach. Oxford: Routledge.

Moreras, Jordi. 2006. ¡Que vuelvan los reyes católicos! Los conflictos en torno a la presencia musulmana en Catalunya. In Politiques de l'Islam y models d'Europa. Barcelona: Caixa Sabadell, pp. 159-86.

Morgan, George, and Scott Poynting, eds. 2016. Global Islamophobia: Muslims and moral panic in the West. New York: Routledge.

Narciso, Laia. 2010. Comentari: Producció científica sobre la immigració negroafricana a Espanya i Catalunya. Revisant els objectius de l'acadèmia. Quaderns-e de l'Institut Català d'Antropologia 15: 76-95.

Narciso, Laia, and Sílvia Carrasco. 2017. Mariama on the Move. Capital migratorio y segundas generaciones en la emigración juvenil española. Migraciones 43: 147-74. [CrossRef]

Ogbu, John U. 1981. School Ethnography: A Multilevel Approach. Anthropology E Education Quarterly 12: 3-29.

Parella, Sònia. 2016. Panoràmica de la pobresa de la població immigrada a Catalunya. Revista d'economia catalana i de sector Public 103: 124-32.

Phoenix, Ann, and Pamela Pattynama. 2006. Editorial. Intersectionality. European Journal of Women's Studies 13: 187-92. [CrossRef]

Roth, Kenneth. 2016. Politics of Fear Threatens Rights. World Report 2016: Events 2015. Philadelphia: Seven Stories Press.

Ryan, Louise. 2013. 'Islam Does Not Change': Young People Narrating Negotiations of Religion and Identity. Journal of Youth Studies 17: 446-60. [CrossRef]

Serracant, Paucoord. 2013. Enquesta a la joventut de Catalunya 2012. In Transicions juvenils i condicions materials d'existència. Barcelona: Generalitat de Catalunya, Col-lecció Estudis, Núm. 34. Volume 1.

Solórzano, Daniel G., and Tara J. Yosso. 2002. Critical Race Methodology: Counter-Storytelling as an Analytical Framework for Education Research. Qualitative Inquiry 8: 23-44. [CrossRef]

Suárez-Orozco, Carola, and Desirée Baolian Qin. 2006. Gendered Perspectives in Psychology: Immigrant Origin Youth. International Migration Review 40: 165-98. [CrossRef]

Valenzuela, Angela. 1999. Subtractive Schooling, Caring Relations, and Social Capital in the Schooling of US-Mexican Youth. Albany: State University of New York Press.

Vives, Luna, and Sesé Sité. 2010. Negra Española, Negra Extranjera: Dos historias de una misma discriminación. Revista de Estudios de Juventud 89: 165-86.

Y1lmaz, Ferruh. 2012. Right-Wing Hegemony and Immigration: How the Populist Far-Right Achieved Hegemony through the Immigration Debate in Europe. Current Sociology 60: 368-80. [CrossRef]

Yılmaz, Ferruh. 2015. From Immigrant worker to Muslim Immigrant: Challenges for Feminism. European Journal of Women's Studies 22: 37-52. [CrossRef]

Yuval-Davis, Nira. 2006. Belonging and the Politics of Belonging. Patterns of Prejudice 40: 197-214. [CrossRef]

Yuval-Davis, Nira. 2007. Intersectionality, Citizenship and Contemporary Politics of Belonging. Critical Review of International Social and Political Philosophy 10: 561-74. [CrossRef]

Yuval-Davis, Nira, Floya Anthias, and Eleonore Kofman. 2006. Secure Borders and Safe Haven: The Gendered Politics of Belonging beyond Social Cohesion. Ethnic and Racial Studies 28: 513-35. [CrossRef] 